\title{
The environmental impacts of lowland paddy rice: A case study comparison between rainfed and irrigated rice in Thailand
}

\author{
Sylvain-Roger Perret ${ }^{1}$ \\ Kwansirinapa Thanawong ${ }^{2}$ \\ Claudine Basset-Mens ${ }^{3}$ \\ Rattanawan Mungkung ${ }^{4}$ \\ ${ }^{1}$ Cirad \\ UMR G-Eau \\ 73 rue J-F Breton \\ 34398 Montpellier cedex 5 \\ France \\ <sylvain.perret@cirad.fr> \\ ${ }^{2}$ Asian Institute of Technology \\ School of Engineering and Management \\ Po Box 4 \\ Klong Luang \\ 12120 Pathumthani \\ Thailand \\ $<$ kwansirinapa.saratis@ait.ac.th> \\ $<$ hi_job_bye@hotmail.com> \\ ${ }^{3}$ Cirad \\ UR Hortsys \\ Boulevard de la Lironde \\ TA B-103/PS4 \\ 34398 Montpellier cedex 5 \\ France \\ <claudine.basset-mens@cirad.fr> \\ ${ }^{4}$ Kasetsart University \\ Faculty of Environment \\ Department of Environmental Technology \\ and Management \\ 10900 Chatuchak \\ Thailande \\ $<$ fscirwm@ku.ac.th>
}

\begin{abstract}
North-eastern Thailand is an essential production area for high-quality fragrant rice for domestic use and export. While rainfed conditions largely prevail, plans to extend irrigation are drafted. This article compares paddy rice production under irrigation and rainfed conditions. Techno-economic performances were analysed jointly with environmental impacts, based upon life cycle analysis, and energy and water use analyses. Data were collected in 2010 from 45 diverse rice cropping systems in the Lam Sieo Yai Basin, according to three systems, namely wet-season rain-fed (Rw), wet-season irrigation (Iw), and dry-season irrigation (Id) systems. Wide-ranging performances and impacts were observed, while cropping practices were relatively homogeneous. Differentiation of systems originated mostly from differences in yield, which were largely impacted by water supply. The results highlight the low performances and high impacts of Id systems. They require mostly blue water, while the two other systems rely primarily on green water. Id systems also require more energy and labour, due to increased water management needs. The productivity of most production factors was higher in Rw and Iw systems. Emissions proved relatively similar across systems, with the exception of $\mathrm{CH}_{4}$, which was markedly lower in Rw systems due to specific water and organic residue management. Id systems systematically emitted more nitrates, phosphates, and pesticides. Rw systems showed the lowest environmental impacts per ha and per kg of paddy rice produced. The average Global Warming Potential was $2.97 \mathrm{~kg} \mathrm{CO}$-eq per kg rice in $\mathrm{Rw}$ systems, 4.87 in Iw systems, and 5.55 in Id systems. This article further discusses the results in view of contrasting perspectives, including societal objectives, farmer income and environmental integrity, and possible irrigation development in north-eastern Thailand.
\end{abstract}

Key words: environmental impact; irrigation; life cycle analysis; productivity; rice.

Subjects: natural resources and environment; vegetal productions; water.

\section{Résumé}

Les impacts environnementaux du riz de bas-fonds : comparaison de systèmes irrigués et pluviaux en Thaïlande

Le Nord-Est de la Thailande est une région essentielle pour la production de riz parfumé de haute qualité à usage domestique et à l'export. Alors que les systèmes pluviaux dominent, des plans d'extension de l'irrigation sont préparés. Cet article compare la production de riz en casier irrigué et en pluvial. Les performances technico-économiques et les impacts environnementaux ont été analysés conjointement, à l'aide des analyses du cycle de vie et des usages de l'énergie et de l'eau. Les données ont été collectées en 2010 dans 45 systèmes de culture du bassin de Lam Sieo Yai, selon trois systèmes : pluvial de saison humide (Rw), irrigué de saison humide (Iw) et irrigué de saison sèche (Id). On observe des performances et des impacts très différenciés, alors que les systèmes sont relativement homogènes. Ces différences entre systèmes proviennent essentiellement des rendements, eux-mêmes influencés par les apports d'eau. Les résultats soulignent les moindres performances et les

To cite this article: Perret SR, Thanawong K, Basset-Mens C, Mungkung R, 2013. The environmental impacts of lowland paddy rice: A case study comparison between rainfed and
Correspondence: S. Perret

doi: 10.1684/agr.2013.0663 irrigated rice in Thailand. Cah Agric 22: 369-77. doi : 10.1684/agr.2013.0663 
impacts forts des systèmes Id. Ils requièrent de l'eau d'irrigation (eau bleue) alors que les autres consomment avant tout les précipitations utiles et le stock d'eau du sol (eau verte). Les systèmes Id consomment aussi plus d'énergie et de main-d'œuvre pour la gestion de l'irrigation. La productivité de la plupart des facteurs de production est supérieure dans les systèmes de saison humide Rw et Iw. Les rejets s'avèrent similaires dans tous les systèmes, à l'exception du $\mathrm{CH}_{4}$, nettement moins émis par Rw en raison des modalités de gestion de l'eau et des résidus de culture. Les systèmes Id rejettent systématiquement plus de nitrates, de phosphates et de pesticides. Les systèmes Rw montrent les impacts les plus faibles, par hectare et par kilo de riz produit. Le potentiel de réchauffement climatique est en moyenne de 2,97 $\mathrm{kg} \mathrm{CO}_{2}$-eq par kilo de riz dans les systèmes Rw, 4,87 dans les systèmes Iw, et 5,55 dans les systèmes Id. Enfin, l'article discute les résultats, au regard des objectifs sociétaux et de ceux des producteurs, du respect de l'environnement, et du possible développement de l'irrigation dans le Nord-Est de la Thaïlande.

Mots clés : analyse du cycle de vie ; impact sur l'environnement ; irrigation ; productivité ; riz.

Thèmes : eau ; productions végétales ; ressources naturelles et environnement.

W orldwide, paddy rice systems provide food, income, and a diversity of ecosystem goods and services (Bouman et al., 2007), yet they also have negative impacts on the environment (Roger et Joulian, 1998; Tilman et al., 2001). Rice production requires large amounts of resources and contributes to pollution in all environmental compartments. Flooded rice grows under anaerobic conditions, which favours methane formation (IPCC, 2006).

Thailand is the world's sixth largest rice producer and largest exporter. Rice is grown on some 10 million hectares of land, with more than half grown in the north-eastern region (Isaan). Rice production in Isaan is currently mostly lowland rain-fed (85\% of paddy land area; only in the wet season) and irrigated (15\% of paddy land cover during the wet season; only $7.5 \%$ during the dry season), and shows low yields of high-quality, high-value varieties (Jasmine fragrant rice for domestic use and export). Isaan produces approximately $80 \%$ of all jasmine rice produced nationwide.

Overall, rice production systems contribute $80 \%$ of freshwater extractions in Thailand, and pesticide-related toxicity has become a major concern. There exist recurring plans to extend irrigation in Isaan (Molle and Floch, 2008), which can be implemented only through further exploitation of the Mekong river and its tributaries and wetlands.
Given the importance of the rice sector in Thailand and growing concerns about its sustainability, this research aims at assessing the environmental impacts of rice cropping systems in Isaan as a main production area. In view of existing plans to extend irrigation in Isaan, the research also compares the advantages of rice production under controlled irrigation and rain-fed conditions in both environmental and economic terms.

\section{Materials and methods}

\section{Study area description}

The Lam Sieo Yai basin $\left(2,875 \mathrm{~km}^{2}\right)$ is located at the heart of the Isaan plateau in North-eastern Thailand. The region has a tropical savanna climate, with two seasons: the dry season between November and April, which commonly includes severe drought conditions, and the monsoon-affected wet season between May and October. Annual rainfall amounts to approximately $900 \mathrm{~mm}$ on average, yet with high inter-annual variability.

Of the total area, $83 \%$ is agricultural land, of which $96 \%$ is covered with paddy fields. In the basin, $75 \%$ of paddy fields are irrigated (i.e. with controlled water supply). The other $25 \%$ are rainfed paddy fields. Lowland rainfed rice is grown only during the wet season, while irrigated rice may be cultivated during both seasons. Rainfed conditions refer to conditions of lowland rice that is cropped under flooding conditions with no control of water supply. Rainfall, soil moisture, and natural runoff alone (green water) provide water to the paddy fields.

\section{Joint LCA and techno- economic analyses}

\section{General approach}

Among other methodologies, life cycle analysis (LCA) has recently emerged as the leading methodology to assess potential environmental impacts in agriculture (Van der Werf and Petit, 2002). This approach is increasingly used in the industry and the agriculture sectors for assessing processes and products and for the development and implementation of environmental policies (EU, 2010a). LCA is a structured, systematic, standardised method (ISO 14040 and 14044) for quantifying the emissions, resources consumed, and environmental and health impacts that are associated with the production and use of goods and services (products). LCA consists of a thorough and systematic inventory (life cycle inventory, LCI) of processes, emissions, resource consumptions, and inputs and outputs related to the provision of a good or service. It then converts the 
inventory into impact indicators as per impact categories. This step is the life cycle impact assessment (LCIA) phase (Baumann and Tillman, 2004; EU, 2010b).

LCA application in agriculture has developed over the last 15 years (Audsley et al., 1997) and addressed most agricultural commodities (Williams et al., 2005). Yet, paradoxically, rice has been rarely studied. To the authors' knowledge, there are only three comprehensive published applications of LCA to rice (Blengini and Busto, 2009; Wang et al., 2010; Hokazono and Hayashi, 2012). The two former compare an alternative, supposedly less impacting, cropping system with an existing one. Wang et al. (2010) studied only one system. In all cases, the assessments focus on virtual systems that represent average, ideal situations, regardless of the diversity of local situations and practices. Basset-Mens et al. (2010) assessed rice LCA literature and highlighted the overall paucity and limitations, including a lack of consideration of the actual diversity of field and farm situations and of water and energy use.

The research is an attempt to better address the actual diversity of existing systems. It collected, analysed, and combined indicators of technoeconomic performances with environmental impact indicators based upon the life cycle approach, at cropping system level. Techno-economic analysis typically results in monetary values as per factor of production while LCA expresses environmental impacts as per selected functional units FU. The FU for LCA is the mass (kg) of raw paddy rice (unmilled) at the farm gate (approximately 15\% moisture content).

Three cropping systems were investigated based upon water management system: wet-season rain-fed rice (Rw), wet-season irrigated rice (Iw), and dryseason irrigated rice (Id). Direct sowing of dry seeds has become predominant in Isaan. The results presented here refer to this planting mode in each water management system.

Primary data were collected by means of field observations and interviews with farmers; data refer to both dry and wet seasons of 2010. Year 2010 received $1,219 \mathrm{~mm}$ of precipitation, which is notably more than the 30-year average $(900 \mathrm{~mm})$. For each system, 15 farm plots were selected with extension officers and farmers, based upon representativeness and local diversity.
The present LCA study covered the rice production systems from the mobilisation of all raw resources and equipment to farm gate (unmilled rice). Figure 1 shows the flow diagram used for the study, where both direct and indirect flows were considered in the inventory.

\section{Joint inventories}

The common technical data and specific data needed for LCI and economic analyses for the main stages of rice production are presented in table 1. The inventory comprises the following processes and operations:

- field operations with machinery;

- field operations performed manually;

- inputs and agro-chemical use;

- yields and market price at the farm gate;

- cultivated areas.

Actual water consumption is unknown in canal, gravity-based conditions. Crop water requirements (CWR) and irrigation water requirements (IWR, blue water), both modelled from soil, crop, and climate data, are usually used as proxies (Allen et al., 1998). Recent versions of the FAO's CropWat (FAO, 1992; Chapagain and Hoekstra, 2011), coupled with water

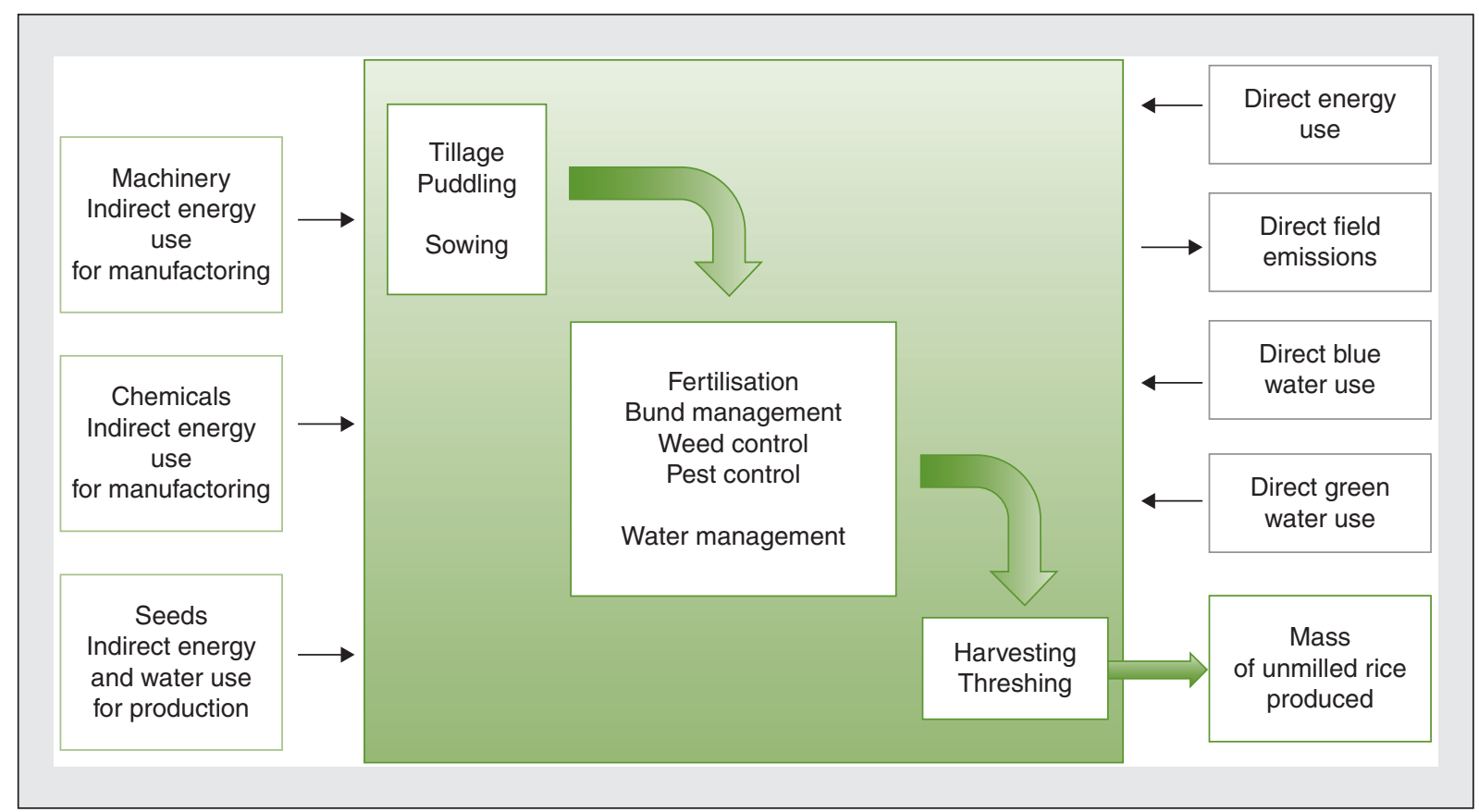

Figure 1. Flow diagram for rice cropping systems: general inventory of inputs and outputs from resources mobilisation to farm gate (unmilled rice).

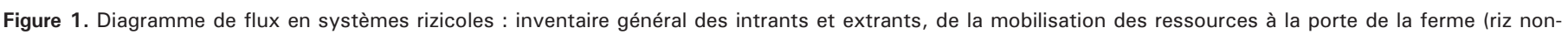
décortiqué). 
Table 1. Type and source of data needed for life cycle inventory (LCI) and economic analyses.

Tableau 1. Type de données et leurs sources pour l'inventaire ACV (analyse du cycle de vie) et les analyses économiques.

\begin{tabular}{|c|c|c|c|}
\hline & Areas of inventory & Data sources & Unit \\
\hline \multirow{5}{*}{$\begin{array}{l}\text { Common technical } \\
\text { data }\end{array}$} & Input use (seeds, chemicals) & Primary data (farm level) & $\mathrm{Kg}$ or $\mathrm{g}$ \\
\hline & $\begin{array}{l}\text { Direct energy consumption } \\
\text { (machinery, portable equipment) }\end{array}$ & Primary data (farm level) & MJ \\
\hline & Water consumption & $\begin{array}{l}\text { Modeling from IWR (Water } \\
\text { balance model and CropWat) }\end{array}$ & $\mathrm{m}^{3}$ \\
\hline & Yield & Primary data (farm level) & $\mathrm{kg} / \mathrm{ha}$ \\
\hline & Land use & Primary data (farm level) & ha/production cycle \\
\hline \multirow[t]{2}{*}{ LCI-specific data } & $\begin{array}{l}\text { Indirect energy consumption } \\
\text { (from manufacturing and } \\
\text { transport of machinery and } \\
\text { chemicals) }\end{array}$ & $\begin{array}{l}\text { Ecoinvent database } \\
\text { (in SimaPro) }\end{array}$ & MJ \\
\hline & Direct field emissions & $\begin{array}{l}\text { Modelling (secondary data } \\
\text { IPCC and tier- } 2 \text { references) }\end{array}$ & Kg substance per \\
\hline \multirow[t]{3}{*}{ Economic data } & $\begin{array}{l}\text { Production costs (labour, } \\
\text { chemicals, machinery, energy) }\end{array}$ & Primary data (farm level) & Thai Baht \\
\hline & $\begin{array}{l}\text { Economic value (total value } \\
\text { product) }\end{array}$ & $\begin{array}{l}\text { Primary data (market price } \\
\text { at farm gate) }\end{array}$ & Thai Baht \\
\hline & Labour & Primary data (farm level) & $\mathrm{h}$ \\
\hline
\end{tabular}

IWR: irrigation water requirements; IPCC: International Panel on Climate Change.

Thai Baht (THB): currency of Thailand, equal to approximately 0.033 US\$ at the time of data collection (2010).

balance modelling in ponding conditions, have been used.

The inventory for the manufacturing and delivery of machinery, agrochemicals and seeds, equipment, machinery, inputs, and energy carriers used during field operations were calculated with SimaPro 7 from field data and based upon existing conversion rates, methods, and databases (Ecoinvent database). These flows are shown on the left side of figure 1. Flows related to direct field emissions, energy use, and blue (irrigation) and green (rainfall) water use are shown on the right side of figure 1. Human labour is being considered only in technoeconomic calculations.

$\mathrm{CH}_{4}$ emissions were modelled based upon tier-1 methods established by the International Panel on Climate Change (IPCC, 2006) for paddy under different water regimes, adjusted with tier-2 baseline emission factors determined by Yan et al. (2003a) for Thailand. For $\mathrm{N}_{2} \mathrm{O}, \mathrm{NH}_{3}$, and $\mathrm{NOx}$ emissions, the methods developed by Yan et al. (2003b) were used. They suggested tier-2 methods for flooded paddy fields in South East Asia. Carbon dioxide was considered neutral (Williams et al.,
2005). The observed average length of cropping cycles is 120 days, from sowing to harvesting.

Water-soluble nitrates and phosphates have been considered to be the two potential pollutants emitted to the water compartments during rice cropping. A similar approach was carried out for both of these pollutants. Because urea and ammonium-based fertilisers prevail in Isaan, direct nitrate emissions result mostly from nitrification and the whole nitrogen cycle and balance, rather than direct fertiliser loss. The principles underlying the nitrate emission assessment are that: i) nitrates form the remaining components of the overall nitrogen mass balance the other components of which were determined in earlier sections; ii) these water-soluble nitrates may leach to the water compartment through surface drainage and deep percolation; and iii) such a portion refers to the ratio between water that is not used by the crop and overall water supply (that is water use efficiency). Accordingly, nitrates potentially leaching from a paddy field are modelled according to a dual $\mathrm{N}$ and water mass balance approach suggested by Brentrup et al. (2000) and Pathak et al. (2004).

A similar approach was applied to phosphates, under similar assumptions regarding the stability of long-term contents, the absence of erosion, and with a similar modelling approach. $P$ inputs from fertiliser were calculated from fertiliser formulae and application doses.

In the cropping systems under study, the pesticides typically used included a molluscicide (metaldehyde), an insecticide (isoprocarb-based with $\mathrm{CaCO}_{3}$ ), and an herbicide (glyphosate); all are hand-sprayed at different stages while the field is flooded most of the time. It was assumed that 100\% of pesticides ultimately end up in both soil and water compartments. Straw and rooting systems are left in the field to decay. It was decided to split emissions equally between soil and water compartments (50\%-50\%).

\section{LC impact assessment}

The selected environmental impact indicators first include resource-use indicators: energy use (EU), freshwater use (WU), and land use (LU). 
It should be noted that no characterisation towards indicators of potential water resource depletion was used. Current methodologies (Pfister et al., 2009) that calculate regional Water Stress Index (WSI) do not provide satisfactory results in tropical monsoon areas. Indeed, the algorithm considers the high monthly variations of precipitations, and results in artificially high WSI. Second, they include environmental impact indicators: eutrophication (EP), acidification (AP), global warming potential for a 100year time horizon $\left(\mathrm{GWP}_{100}\right)$, freshwater aquatic ecotoxicity (FWAE), and ozone depletion (ODP). These impact categories were chosen based upon their widespread use in agricultural LCA studies, allowing for comparison. More specifically, FWAE was selected because freshwater is a key compartment of paddy rice cropping systems. Characterisation was performed with the SimaPro platform using CML baseline 2002/world, 1995 methodology. All units are provided in table 2. GWP $_{100}$ was calculated according to IPCC (Guinée et al., 2002). EP, FWAE, and ODP were calculated with factors recommended by Guinée et al. (2002). AP was calculated using the generic method proposed by Heijungs et al. (1992). Energy use was calculated based upon direct and indirect fossil fuel use, including physical (machinery) and chemical (fertilisers and pesticides) energy. Crop evaporative consumption was modelled with water balance and CropWat models (FAO, 1992); it included the evaporation of rainfall from cropland (green water use, $\mathrm{WU}_{\mathrm{g}}$ ) and the evaporation of irrigation water from cropland (blue water use, $\mathrm{WU}_{\mathrm{b}}$ ). Land use refers to the loss of land as a resource in the sense of being temporarily unavailable for other purposes. Details on CML 2002 calculations, impact factors, and normalisation may be found in Guinée et al. (2002). CML 2002 methodologies and necessary databases are included in the SimaPro 7.3 modelling platform, which was used for this research. Commercial pesticides were modelled according to their active ingredients and the inventory data from Ecoinvent database within SimaPro.

\section{Results}

\section{Utilisation of production factors and performances}

Table 3 shows the techno-economic performances of the three cropping systems per area cultivated (ha). The results highlight the low performances of Id systems, the production factor requirements of which are systematically higher than those of the two other systems. In addition, the Id system yielded markedly lower production. The Id system also requires mostly blue water, while the other two rely predominantly on green water. The Id system requires three pumping episodes, on average, to replenish ponding conditions in paddy fields; therefore, it requires more labour and energy (pumps).

Labour, energy, and pesticide requirements are markedly lower in rain-fed conditions due to lesser water management requirements (no pumping) and an absence of treatment against the golden snail (Pomacea canaliculata) which cannot reproduce during the cropless dry season of rain-fed plots.

The high level of homogeneity of fertiliser and pesticide application practices within each cropping system resulted in relatively homogeneous production costs per system, however, there were diverse outcomes in terms of yield and, therefore, of gross and net income. Net income per system was wide-ranging, with the Id system being the least

\section{Table 2. Environmental impact indicators in selected rice cropping systems in the Lam Sieo Yai basin in 2010.}

Tableau 2. Indicateurs d'impacts environnementaux de systèmes rizicoles du bassin de Lam Sieo Yai, année 2010.

\begin{tabular}{|c|c|c|c|c|c|c|c|c|c|c|c|}
\hline \multirow{3}{*}{$\begin{array}{l}\text { Impact } \\
\text { indicator }\end{array}$} & & \multirow{3}{*}{$\begin{array}{l}\text { Reference } \\
\text { unit }\end{array}$} & \multicolumn{3}{|c|}{ Rain-fed } & \multicolumn{3}{|c|}{ Wet-season irrigated rice } & \multicolumn{3}{|c|}{ dry-season irrigated rice } \\
\hline & & & Max. & Median & Min. & Max. & Median & Min. & Max. & Median & Min. \\
\hline & & & \multicolumn{9}{|c|}{ Ref. Unit/1 kg of paddy rice } \\
\hline \multirow{5}{*}{$\begin{array}{l}\text { Output-related } \\
\text { indicators }\end{array}$} & $\mathrm{GWP}_{100}$ & $\mathrm{~kg} \mathrm{CO}$-eq & 3.450 & 2.970 & 2.840 & 5.120 & 4.870 & 4.510 & 6.200 & 5.550 & 5.060 \\
\hline & EP & $\mathrm{kg} \mathrm{PO}$-eq & 0.093 & 0.075 & 0.070 & 0.087 & 0.079 & 0.069 & 0.119 & 0.099 & 0.084 \\
\hline & AP & $\mathrm{kg} \mathrm{SO} \mathrm{S}_{2}$-eq & 0.052 & 0.044 & 0.042 & 0.044 & 0.040 & 0.036 & 0.057 & 0.049 & 0.043 \\
\hline & ODP & mg CFC-11-eq & 0.084 & 0.071 & 0.067 & 0.073 & 0.068 & 0.061 & 0.096 & 0.082 & 0.072 \\
\hline & FWAE & $\mathrm{kg} \mathrm{1,4-DB} \mathrm{eq}$ & 0.329 & 0.276 & 0.261 & 0.325 & 0.303 & 0.269 & 0.431 & 0.371 & 0.323 \\
\hline \multirow{3}{*}{$\begin{array}{l}\text { input-related } \\
\text { indicators }\end{array}$} & WU & $\mathrm{m}^{3}$ & 3.153 & 2.646 & 2.518 & 2.886 & 2.676 & 2.395 & 3.87 & 3.317 & 2.902 \\
\hline & LU & ha & 0.00050 & 0.00042 & 0.00040 & 0.00041 & 0.00038 & 0.00034 & 0.00053 & 0.00046 & 0.00040 \\
\hline & EU & MJ & 8.680 & 7.252 & 6.913 & 8.037 & 7.44 & 6.6 & 9.774 & 9.529 & 7.913 \\
\hline
\end{tabular}

Results are expressed per kg rice produced.

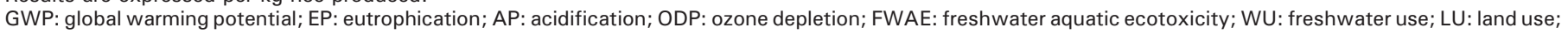
EU: energy use. 
Table 3. Production factor use and techno-economic performances per hectare in selected rice cropping systems in the Lam Sieo Yai basin in 2010.

Tableau 3. Utilisation des facteurs de production et performances technico-économiques de systèmes rizicoles du bassin de Lam Sieo Yai, année 2010.

\begin{tabular}{|c|c|c|c|c|c|c|c|c|c|c|}
\hline \multirow{3}{*}{$\begin{array}{l}\text { Production factors } \\
\text { and performances }\end{array}$} & \multirow{3}{*}{$\begin{array}{l}\text { Reference } \\
\text { Unit }\end{array}$} & \multicolumn{3}{|c|}{ Rain-fed } & \multicolumn{3}{|c|}{ Wet-season irrigated rice } & \multicolumn{3}{|c|}{ Dry-season irrigated rice } \\
\hline & & Max. & Median & Min. & Max. & Median & Min. & Max. & Median & Min. \\
\hline & & \multicolumn{9}{|c|}{ Ref. Unit/ha } \\
\hline Labour & man hr. & 8.494 & 6.625 & 5.677 & 15.234 & 11.949 & 8.013 & 16.447 & 16.447 & 11.250 \\
\hline Fertiliser & $\begin{array}{l}\text { kg of } \\
\text { fertiliser }\end{array}$ & 625.00 & 625.00 & 625.00 & 687.50 & 687.50 & 687.50 & 687.50 & 687.50 & 687.50 \\
\hline Pesticide & $\begin{array}{l}\text { kg of active } \\
\text { matter }\end{array}$ & 5.070 & 5.070 & 5.070 & 7.356 & 7.356 & 7.356 & 11.575 & 11.575 & 11.575 \\
\hline Total water & $\mathrm{m}^{3}$ & 6,285 & 6,285 & 6,285 & 7,026 & 7,026 & 7,025 & 7,256 & 7,256 & 7,256 \\
\hline Green water & $\mathrm{m}^{3}$ & 6,285 & 6,285 & 6,285 & 6,285 & 6,285 & 6,285 & 1,172 & 1,172 & 1,172 \\
\hline Blue water & $\mathrm{m}^{3}$ & 0.288 & 0.250 & 0.208 & 740.539 & 740.539 & 740.444 & 6,084 & 6,084 & 6,084 \\
\hline Total energy & MJ & 17,360 & 17,281 & 17,222 & 19,590 & 19,530 & 19,388 & 20,846 & 19,783 & 18,327 \\
\hline Production cost & THB & 20,868 & 20,843 & 20,822 & 22,435 & 22,354 & 22,243 & 23,415 & 22,943 & 20,884 \\
\hline Gross income & THB & 28,521 & 27,095 & 22,817 & 33,512 & 29,947 & 27,808 & 30,000 & 26,250 & 22,500 \\
\hline Net income & THB & 7,653 & 6,252 & 1,995 & 11,077 & 7,593 & 5,565 & 6,585 & 3,307 & 1,616 \\
\hline
\end{tabular}

Note: THB $=$ Thai Baht, currency of Thailand, equal to approximately 0.033 US\$ at the time of data collection (2010).

profitable and the most variable. Conditions during the dry season are less favourable temperature-wise and more uncertain and variable in terms of water management. Iw systems showed higher homogeneity of results and a potential for the highest yields and net income.

Table 4 shows the productivities of production factors and the technoeconomic performances of the three rice cropping systems. Overall, the results confirm that the productivities of most factors are higher in the Rw system, in which farmers produce more rice per labour unit, pesticide unit, and total energy unit. Interestingly, the productivities in the Rw and Iw systems are similar with regards to factors such as fertiliser, total water, and green water. Return on investment (mass of rice produced per production cost) is slightly higher in the Iw system compared to the Rw system $(0.117 \mathrm{~kg} / \mathrm{THB}$ and $0.114 \mathrm{~kg} /$ THB, respectively; [ 1 THB $=0.03$ US\$]) and is lowest in the Id system $(0.095 \mathrm{~kg} / \mathrm{THB})$. Median yields (land productivity) vary from $2,625 \mathrm{~kg} /$ ha in the Iw system to 2,375 in the $\mathrm{Rw}$ system, and 2,188 in the Id system. Finally, the amount of rice per net income unit is markedly lower in the Iw system $(0.297 \mathrm{~kg} / \mathrm{THB}$ earned as net income) and Rw system (0.310) compared to the Id system, in which farmers need to produce twice as much rice $(0.662 \mathrm{~kg})$ to obtain the same net income.

\section{Environmental impacts}

On a land use basis, LCIA results show that GWP 100 is markedly different between rain-fed and irrigated systems, Iw showing the highest impact (table 2). Differences in $\mathrm{CH}_{4}$ emissions (because of straw incorporation and water management during pre-cultivation times) account for this result. In all other impact categories, Rw systems systematically show lower impacts per ha than Iw and Id systems, with the latter having the highest impacts. However, AP, ODP, and total water use are of the same magnitude across systems (figure 2).
On a rice mass basis, differences are more marked, due to yield differences. In table 2, the environmental impacts for selected impact categories, per kg of unmilled rice produced, are reported. The impacts of Id systems are higher than those of the two other systems due to the lower yields. GWP $_{100}$ becomes higher in Id systems $\left(5.55 \mathrm{~kg} \mathrm{CO}_{2}-\mathrm{eq}\right)$ compared to Iw systems (4.87). Rw systems remain the least impacting, with $2.97 \mathrm{~kg} \mathrm{CO}_{2}-$ eq. Total energy use is higher in Id systems $(9.64 \mathrm{MJ} / \mathrm{kg}$ rice) compared to Iw and Rw systems (7.50 and 7.29, respectively). Figure 3 reports a relative comparison of selected environmental impacts by the three systems, and highlights the same differences, and the high impacts of Id systems. It was calculated that Rw systems value each ton of $\mathrm{CO}_{2}$-eq emitted at 4,040 THB, or approximately 134 US\$. Iw and Id systems value each ton of $\mathrm{CO}_{2}$-eq emitted at 82 and 72 US\$, respectively.

Figure 2 shows the diversity of water consumption in the sampled cropping systems. Variations in water use are 
Table 4. Productivity of production factors and techno-economic performances in selected rice cropping systems in the Lam Sieo Yai basin in 2010.

Tableau 4. Productivités des facteurs de production et performances technico-économiques de systèmes rizicoles du bassin de Lam Sieo Yai, année 2010.

\begin{tabular}{|c|c|c|c|c|c|c|c|c|c|c|}
\hline \multirow{3}{*}{$\begin{array}{l}\text { Production factors } \\
\text { and performances }\end{array}$} & \multirow{3}{*}{$\begin{array}{l}\text { Reference } \\
\text { Unit }\end{array}$} & \multicolumn{3}{|c|}{ Rain-fed } & \multicolumn{3}{|c|}{ Wet-season irrigated rice } & \multicolumn{3}{|c|}{ Dry-season irrigated rice } \\
\hline & & Max. & Median & Min. & Max. & Median & Min. & Max. & Median & Min. \\
\hline & & \multicolumn{9}{|c|}{$\mathrm{Kg}$ of paddy rice/Ref. Unit } \\
\hline Land & ha & 2,500 & 2,375 & 2,000 & 2,938 & 2,625 & 2,438 & 2,500 & 2,188 & 1,875 \\
\hline Labour & man hr. & 440.37 & 358.49 & 235.47 & 366.60 & 219.69 & 160.00 & 222.22 & 133.00 & 160.00 \\
\hline Fertiliser & $\begin{array}{l}\mathrm{kg} \text { of } \\
\text { fertiliser }\end{array}$ & 4.000 & 3.800 & 3.200 & 4.273 & 3.818 & 3.545 & 3.636 & 3.182 & 2.727 \\
\hline Pesticide & $\begin{array}{l}\mathrm{kg} \text { of active } \\
\text { matter }\end{array}$ & 493.10 & 468.44 & 394.48 & 399.32 & 356.84 & 331.35 & 215.98 & 188.98 & 161.99 \\
\hline Total water & $\mathrm{m}^{3}$ & 0.398 & 0.378 & 0.318 & 0.418 & 0.374 & 0.347 & 0.345 & 0.301 & 0.258 \\
\hline Green water & $\mathrm{m}^{3}$ & 0.398 & 0.378 & 0.318 & 0.467 & 0.418 & 0.388 & 2.133 & 1.866 & 1.600 \\
\hline Blue water & $\mathrm{m}^{3}$ & 12,000 & 9,500 & 6,933 & 3.97 & 3.545 & 3.292 & 0.411 & 0.360 & 0.308 \\
\hline Total energy & MJ & 0.145 & 0.1379 & 0.115 & 0.15151 & 0.13441 & 0.12442 & 0.1264 & 0.10494 & 0.1023 \\
\hline Production cost & THB & 0.120 & 0.114 & 0.096 & 0.131 & 0.117 & 0.110 & 0.107 & 0.095 & 0.090 \\
\hline Gross income & THB & 0.083 & 0.083 & 0.083 & 0.083 & 0.083 & 0.083 & 0.083 & 0.083 & 0.083 \\
\hline Net income & THB & 0.629 & 0.310 & 0.274 & 0.348 & 0.287 & 0.229 & 1.160 & 0.662 & 0.380 \\
\hline
\end{tabular}

Note: THB = Thai Baht; currency of Thailand, equal to approximately 0.033 US\$ at the time of data collection (2010).

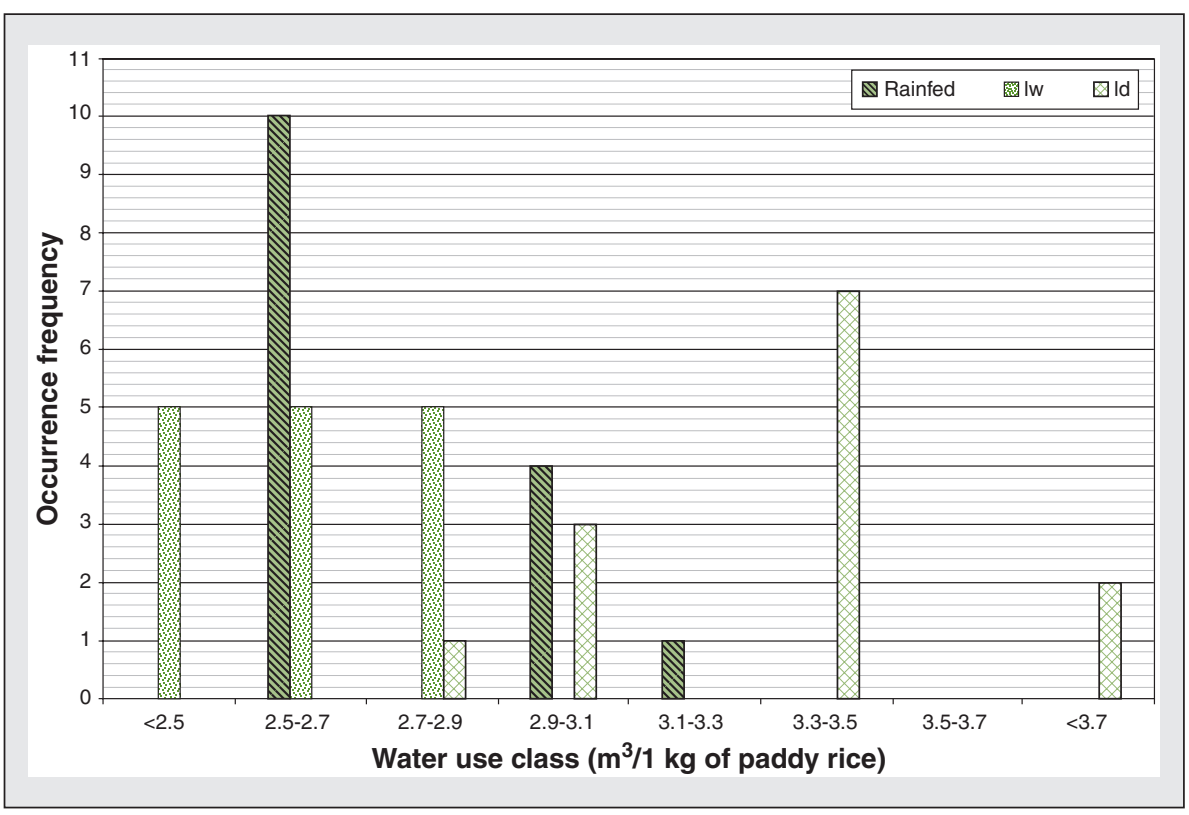

Figure 2. Total water use (WU) per kg of paddy rice produced, modelled for the 45 rice cropping systems (wet and dry seasons in 2010).

Figure 2. Usage total en eau par kilo de paddy produit, modélisé pour les 45 systèmes rizicoles (saisons humide et sèche 2010).

Rainfed; Iw: Irrigated wet season; Id: Irrigated dry season. especially marked in dry-season irrigation, showing diversity of practices in farmers' decisions and strategies regarding water supplies (pumping episodes).

A contribution analysis showed the relative contribution of cropping subsystems to each impact category. Direct field emissions to air and water overwhelmingly contribute to AP, EP, $\mathrm{GWP}_{100}$, and FWAE; they mostly depend on water management practices for methane emissions, and both agro-chemical and water management for other emissions. Field operations with machinery and equipment contribute $20 \%$ of all energy use and a large part of ODP. Fertiliser application and manufacturing contribute a majority of total energy use, a large part of ODP, FWUE, and a marginal amount to AP, EP, and GWP 100 . Rice seeds contribute marginally to FWAE and EU. Pesticide application requires small amounts of water, and the main contributor to WU remains crop water use. 


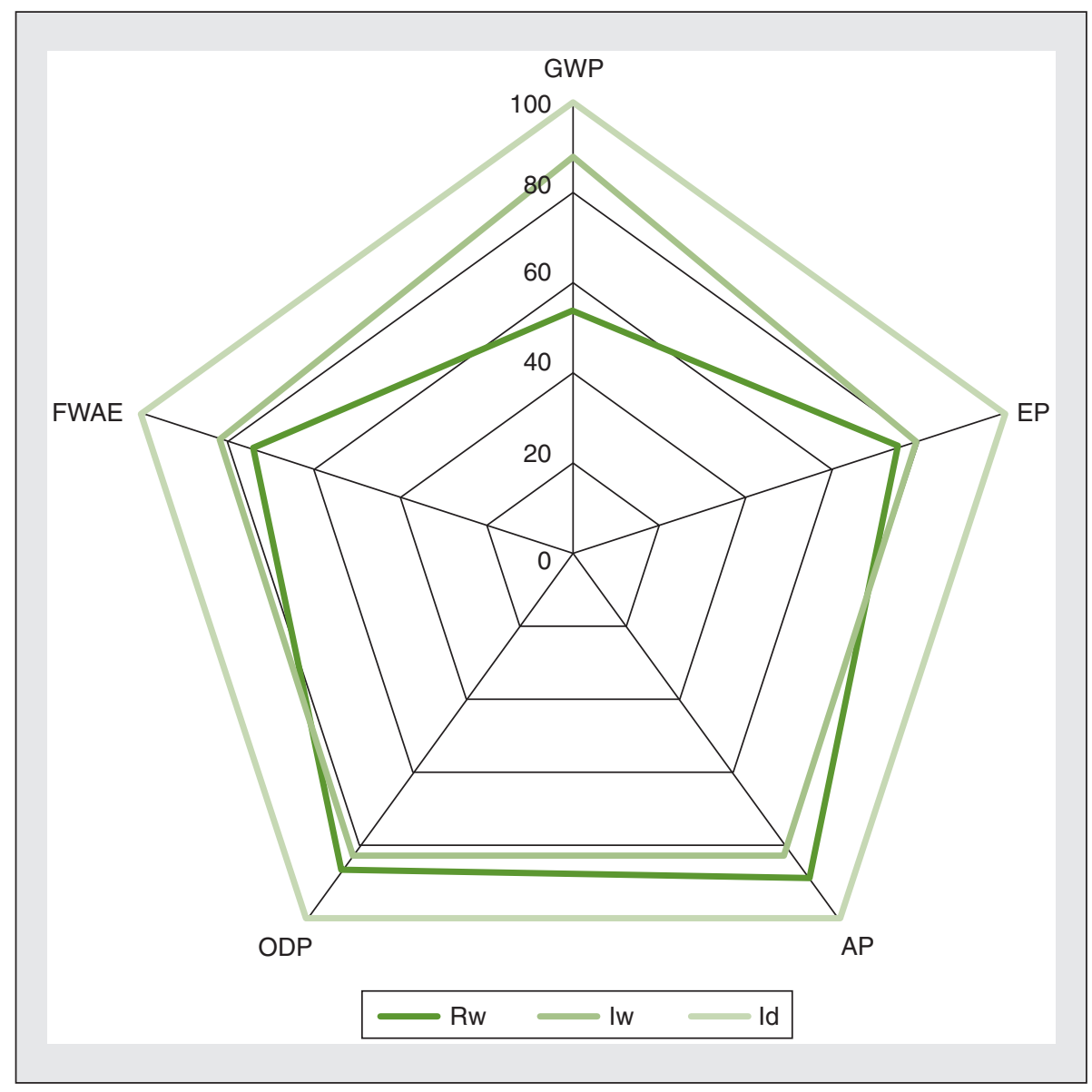

Figure 3. Comparative environmental impacts of the three rice cropping systems.

Figure 3. Comparaison des impacts environnementaux des trois systèmes rizicoles. Rw: Rain-fed; Iw: Irrigated wet season; Id: Irrigated dry season. FWAE: freshwater aquatic ecotoxicity; GWP: global warming potential; EP: eutrophication; ODP: ozone depletion; AP: acidification.

\section{Discussion}

\section{and conclusion}

In spite of the relative homogeneity of cropping practices, overall and per sub-cropping system, outcomes in both economic and environmental terms show significant diversity. Net income and global warming potential are particularly wide-ranging in the different systems. This variation mostly results from large differences in yields, overall and per subcropping system. Yields and resulting net incomes are more diverse (less stable) in Rw and Id systems compared to Iw systems, due to a lack of control of the water supply and a lack of water, respectively. It was observed that, while Id farmers usually try to refill their paddy fields three times per season, many do not actually obtain enough water (e.g., canal tail-enders). The precipitation levels of the dry season of 2010 were relatively high compared to 30-year average precipitation levels; the lack of water for Id system farmers could have been even more damaging to yields in normal or drier years. This would potentially result in lower yields and increased differences in performances and impacts between wet-season and dry-season systems. The same rationale applies to $\mathrm{Rw}$ systems, which showed relatively high performances and low impacts in 2010, but would perform well below the level of Iw systems under drier conditions.
The results contribute insights and data to the debate on the need to further develop irrigation in the context of Isaan, with necessary precautions due to limited data. Rain-fed systems are reasonable alternatives and compete well against irrigation during the wet season. Proponents of irrigation development in Isaan advocate that rain-fed systems only provide cropping opportunity during the wet season and force farmers to resort to alternative livelihoods in the dry season.

For a societal objective of higher rice production and limitation of outmigration, irrigation during both seasons guarantees higher production overall, and keeps farmers busy all year round. From a farmer's viewpoint, dry-season irrigation requires more inputs, higher costs and labour, and ultimately shows lower efficiency. Furthermore, if environmental integrity is factored into decisions, irrigation during the dry season is clearly not the best option. Furthermore, the shift from traditional transplanting to direct sowing of dry seeds illustrates the fact that rice farmers in Isaan are seeking labour efficiency and time-saving solutions, rather than high yields, in a context of labour scarcity, massive seasonal outmigration, and diversified rural livelihood systems. Direct seedling results in lower yields, yet with lower labour requirements.

All results converge and establish that dry-season irrigated systems are performing less well than other systems. They use blue water, require more energy, labour, and agrochemicals, and ultimately yield lower production. As a result, gross and net incomes are lower. Although these results refer to only one year, they tend to account for why only half of irrigated land is actually cultivated during the dry season.

Also, there is a striking match between $\mathrm{Rw}$ and Iw systems. Indeed, performances of rain-fed and wet-season irrigated rice are comparable in both economic and environmental terms. The productivities of most production factors are higher in $\mathrm{Rw}$ systems, although Iw systems yield higher production. Yet again, it must be reiterated that 2010 was a wet year, favourable to Rw systems.

Direct field emissions are comparable in all systems, with the notable 
exception of $\mathrm{CH}_{4}$, which is markedly lower in Rw systems due to water and organic residue management. All environmental impacts are higher in Id systems, whether they are expressed per area used or per mass product. The type of research performed here is demanding. It is multidisciplinary by nature, requires a huge primary data basis, and involves complex modelling. However, the methodological combination shows great potential for multi-criteria assessment of cropping systems and allows for detailed eco-efficiency analyses.

\section{References}

Allen RG, Pereira LS, Raes D, Smith M, 1998. Guidelines for computing crop water requirements. Irrigation \& Drainage Paper, 56. Rome : FAO.

Audsley E, Alber S, Clift R, Cowell S, Crettaz P, Gaillard G, et al., 1997. Report on Concerted Action AIR3-CT94-2028. "Harmonisation of Environmental Life Cycle Assessment for Agriculture". Brussels: European Commission, DG VI Agriculture.

Basset-Mens C, Benoist A, Bessou C, Tran T, Perret $\mathrm{SR}, 2010$. Is LCA-based eco-labelling reasonable? The issue of tropical food productions. International conference on Life Cycle Assessment in the agrifood sector.(VII).

Baumann $\mathrm{H}$, Tillman A, 2004. The hitchhiker's guide to LCA: An orientation in life cycle assessment methodology and application. Lund (Sweden): Studentlitteratur.

Blengini GA, Busto M, 2009. The life cycle of rice: LCA of alternative agri-food chain management systems in Vercelli (Italy). Journal of Environmental Management $90: 1512-22$.

Bouman B, Barker R, Humphreys E, Tuong TP, 2007. Rice: feeding the billions. In: Molden D, ed. Water for Food, Water for Life. London; Colombo: Earthscan; International Water Management Institute.
Brentrup F, Küsters J, Lammel J, Kuhlmann H, 2000. Methods to estimate on-field nitrogen emissions from crop production as an input to LCA studies in the agricultural sector. International Journal of LCA 5 : 349-57.

Chapagain AK, Hoekstra AY, 2011. The blue, green and grey water footprint of rice from production and consumption perspectives. Ecological Economics $70: 749-58$

European Union, 2010a. International Reference Life Cycle Data System - ILCD Handbook - General Guide for LCA. Provisions and action steps. Ispra (Italy); Luxemburg: European Commission, Joint Research Centre, Institute for Environment and Sustainability; Office of the European Union Publisher.

European Union, 2010b. International Reference Life Cycle Data System - ILCD Handbook - Analysis of existing environmental impact assessment methodologies for use in LCA. Ispra (Italy); Luxemburg: European Commission, Joint $\mathrm{Re}$ search Centre, Institute for Environment and Sustainability; Office of the European Union Publisher.

FAO, 1992. CROPWAT - A computer program for irrigation planning and management. FAO Technical Irrigation and Drainage paper, 46. Rome: FAO.

Guinée JB, Gorrée M, Heijungs R, Huppes G, Kleijn $\mathrm{R}$, de Koning A, et al., 2002. Life cycle assessment. An operational guide to the ISO standards. Leiden (The Netherlands): Centre of Environmental Science, Leiden University.

Heijungs R, Guinée JB, Huppes G, Lankreijer RM, Udo de Haes HA, Wegener Sleeswijk A, et al. 1992. Environmental Life Cycle Assessments of Products, Guide and Backgrounds. Leiden (The Netherlands): Centre of Environmental Science, Leiden University.

Hokazono S, Hayashi K, 2012. Variability in environmental impacts during conversion from conventional to organic farming: a comparison among three rice production systems in Japan. Journal of Cleaner Production 28 : 101-12.

IPCC, 2006. Guidelines for National Greenhouse Gas Inventories. www.ipcc-nggip.iges.or.jp/public/2006gl/index.htm.
Molle F, Floch P, 2008. Megaprojects and socia and environmental changes: The case of the Thai "Water Grid". Ambio 37 : 199-204.

Pathak BK, Kazama F, lida T, 2004. Monitoring of nitrogen leaching from a tropical paddy field in Thailand. Agricultural Engineering International: the CIGR Journal of Scientific Research and Development VI: Manuscript LW 04015.

Pfister S, Koelhler A, Hellweg S, 2009. Assessing the environmental impacts of freshwater consumption in LCA. Environmental Science and Technology $43: 4098-104$

Roger PA, Joulian C, 1998. Environmental impacts of rice cultivation. In: Chataigner J, ed. Rice quality: a pluridisciplinary approach. Cahiers Options Méditerranéennes, 24 (3) International Symposium, 1997/11/24-27, Nottingham (Great Britain). Montpellier : CIHEAM-IAMM.

Tilman D, Fargione J, Wolff B, D'Antonio C, Dobson A, Howarth R, et al., 2001. Forecasting agriculturally driven global environmental change. Science 292 : 281-4.

Van der Werf HMG, Petit J, 2002. Evaluation of the environmental impact of agriculture at the farm level: a comparison of twelve indicator-based methods. Agriculture, Ecosystems and Environment 93 : 131-45.

Wang M, Xia X, Zhang Q, Liu J, 2010. The life cycle assessment of a rice production system in Taihu region, China. International Journal of Sustainable Development and World Ecology 17 : 157-61.

Williams AG, Audsley E, Sandars DL, 2005. Final Report to Defra on Project ISO205: Determining the environmental burdens and resource use in the production of agricultural and horticultural commodities. London: Department of Environment, Food, and Rural Affairs (Defra).

Yan X, Ohara T, Akimoto H, 2003a. Development of region-specific emission factors and estimation of methane emission from rice fields in the East, Southeast and South Asian countries. Global Change Biology 9 : 237-54.

Yan X, Akimoto H, Ohara T, 2003b. Estimation of nitrous oxide, nitric oxide and ammonia emissions from croplands in East, Southeast and South Asia. Global Change Biology 9 : 1080-96. 